\title{
Color change and thermogravimetric analysis of thermally treated Eucalyptus grandis wood
}

\author{
Emilin Joma da Silva*, Victor Gonçalves Cremonez, Silvana Nisgoski \\ ${ }^{1}$ Institute for Wood Science, University Hamburg, Hamburg, Germany. \\ ${ }^{2}$ Departamento de Engenharia e Tecnologia Florestal, Universidade Federal do Paraná, Curitiba, PR, Brasil.
}

\begin{abstract}
Eucalyptus grandis wood was thermally treated at two different temperatures $\left(150{ }^{\circ} \mathrm{C}\right.$ and $\left.200{ }^{\circ} \mathrm{C}\right)$ in a muffle furnace with steam. The surface color change was measured right after the treatment and in wood samples stored for two years inside a carton box without light exposure. Samples were analyzed by thermogravimetry to detect variation of thermal degradation behavior for different treatment temperatures. Thermally treated wood was darker when compared to control samples. The storage time influenced the wood surface color, with the surface becoming darker and redder. Thermogravimetric analysis revealed a peak of wood degradation between $300^{\circ} \mathrm{C}$ and $400{ }^{\circ} \mathrm{C}$ for thermally treated samples.
\end{abstract}

Keywords: thermal treatment, colorimetry, wood degradation, hardwood

\section{Introduction}

The genus Eucalyptus is a fast growing hardwood, extensively planted in South America and Sub-Saharan Africa. The use of Eucalyptus for lumber and plywood has intensified due its availability. It is well known that wood can suffer fungal and insect attack, damaging its mechanical properties and visual appearance. One of the techniques to improve resistance against decay is the application of thermal treatment. Based on temperature exposure between $180{ }^{\circ} \mathrm{C}$ and $260{ }^{\circ} \mathrm{C}$, thermal treatment of wood is an eco-friendly preservation process (HILL, 2006; CADEMARTORI et al., 2014). This method has been recognized also as useful to improve dimensional stability (CALONEGO et al., 2014). Several commercial processes have been introduced in Europe: The Thermowood process in Finland, the Plato process in Holland, the Bois Perdure and Retification processes in France, and Huber Holz in Austria (ESTEVES; PEREIRA, 2009). In 2015, the Thermowood process accounted for some $60 \%$ of Europe's production of 300,000 $\mathrm{m}^{3}$ of thermally treated wood (SANDBERG; KUTNAR, 2015; THERMOWOOD, 2016).

This treatment is also an alternative to make light colored wood species darker and provide an optical appearance similar to several tropical species (SUNDQVIST; MORÉN, 2006; ESTEVES; PEREIRA, 2009; MOURA; BRITO, 2011; MOURA et al., 2012a). The darkening degree is closely related to the temperature and time of heat exposure. Color changes take place due to modifications in the chemical structure of wood, related to thermal degradation of hemicellulose and lignin, as well as condensation and migration of extractives to the wood surface. This phenomenon has been also observed for wood submitted to hydrothermal treatment (SUNDQVIST; MORÉN, 2002; MORI et al., 2004; VARGA; ZEE, 2008; ZANUNCIO et al., 2014).

Progressive wood heating at temperature below $140{ }^{\circ} \mathrm{C}$ result in loss of water (free and bonded) and volatilization of extractives, while up to $180{ }^{\circ} \mathrm{C}$ several chemical 
transformations take place, and carbonization occurs above $250{ }^{\circ} \mathrm{C}$, with formation of $\mathrm{CO}_{2}$ and other degradation products (ESTEVES; PEREIRA, 2009). According to Moura et al. (2012b), the extractives level changes during thermal treatment, with volatilization tending to diminish when temperature reaches $160{ }^{\circ} \mathrm{C}$ and then increase at higher temperatures.

To investigate the degradation intensity of thermal modification, thermogravimetric analysis (TG) can be useful. This analysis is an effective tool to detect the mass loss related to the temperature increase during thermal degradation. The mass loss of cellulose, hemicelluloses and lignin can be analyzed under defined conditions in the kinetic regime. Cellulose degrades at temperature between 315 and $400{ }^{\circ} \mathrm{C}$, hemicelluloses between 190 and $360{ }^{\circ} \mathrm{C}$, and lignin between 100 and $900^{\circ} \mathrm{C}$ (PEREIRA et al., 2013).

The objective of this study was to evaluate color changes and decomposition of chemical components two years after thermal treatment, providing a dataset for application of stored heat-treated wood.

\section{Material and Methods}

\section{Material}

Eucalyptus grandis logs were harvested in a ten-year-old commercial plantation, located in Tacuarembó State, Uruguay. After wood processing, the timber was transported by plane to Germany and stored in a conditioned room, without temperature fluctuations and humidity change, for six months. The initial moisture content (IMC) was measured by the oven-drying method. Samples were chamber acclimatized $\left(20{ }^{\circ} \mathrm{C}, 65 \%\right.$ relative humidity) to stabilize the equilibrium moisture content (EMC) at $12 \%$. Initial and final density at $12 \%$ was determined by dividing the weight by volume at $12 \%$.

\section{Thermal treatment}

The timber samples were divided into three groups. Two groups were thermally treated in a modified muffle furnace with saturated steam atmosphere. Treatment 1 (T1) was carried out until $150{ }^{\circ} \mathrm{C}$ (heating rate: $0.36{ }^{\circ} \mathrm{C} \cdot \mathrm{min}^{-1}$ ) and maintained for 4 hours. Treatment 2 (T2) involved heating to $200{ }^{\circ} \mathrm{C}$ (heating rate: $0.75^{\circ} \mathrm{C} \cdot \mathrm{min}^{-1}$ ), maintained for 3 hours. After treatment, the samples were kept during 24 hours inside the muffle furnace without heat. This cooling time provided stress relief, avoiding micro cracks. The third sample group did not undergo heat treatment (control samples: CS). CS samples were pre-dried during 24 hours at $80^{\circ} \mathrm{C}$ in the muffle furnace and conditioned $\left(20^{\circ} \mathrm{C}, 65 \%\right)$ for around three months.

\section{Color measurement}

The first color measurement (only at tangential/radial face) was carried out after the cooling with a Konica Minolta CR-310 spectrophotometer. After this procedure, samples were stored for two years inside a carton box, to avoid light exposure, as well as temperature and humidity fluctuations. The second measurement was carried out with a Konica Minolta CM-5 spectrophotometer. This second analysis evaluated the color parameters along the three axes of wood fiber directions: tangential, radial and transversal.

Evaluation of color changes was performed according the Commission Internationale de L'Éclairage (CIE). This method involves three parameters: lightness $\left(\mathrm{L}^{*}\right)$ from $0 \%$ (black) to $100 \%$ (white); $\mathrm{a}^{*}$ from green $(-\mathrm{a})$ to red $(+\mathrm{a})$; and $\mathrm{b}^{*}$ from blue (-b) to yellow $(+b)$. Chroma $(C)$, hue angle $\left(h^{\star}\right)$, and color change $\Delta \mathrm{E}^{\star}$ were calculated according to Equations 1, 2 and 3:

$$
\begin{aligned}
& \mathrm{C}=\sqrt{\left(\mathrm{a}^{\star}\right)^{2}+\left(\mathrm{b}^{\star}\right)^{2}} \\
& \mathrm{~h}^{\star}=\arctan \left(\frac{\mathrm{b}^{\star}}{\mathrm{a}^{\star}}\right)
\end{aligned}
$$




$$
\Delta \mathrm{E}^{\star}=\sqrt{\left[\left(\Delta \mathrm{L}^{\star}\right)^{2}+\left(\Delta \mathrm{a}^{*}\right)^{2}+\left(\Delta \mathrm{b}^{*}\right)^{2}\right]}
$$

The chroma measures the color saturation (intensity) or the distance between color and the center of the chromatic plane. The hue angle is measured around the $\mathrm{L}^{*}$ axis. An angle of $0^{\circ}$ indicates the red hue and $90^{\circ}$ indicates yellow hue.

\section{Thermogravimetric Analysis}

The sample groups were investigated with a Setaram Micro SETSYS S60/58798. To fit inside the testing machine balance, wood splinters of all samples were crushed in a laboratory grinder. Approximately $10 \mathrm{mg}$ of each sample group was analyzed. The procedure adopted a heating rate of $10{ }^{\circ} \mathrm{C} \mathrm{min}{ }^{-1}$ under argon flux $\left(20 \mathrm{~mL} \mathrm{~min}^{-1}\right)$. The analysis was performed from $25^{\circ} \mathrm{C}$ to $600^{\circ} \mathrm{C}$.

\section{Statistical analysis}

Descriptive statistics were calculated and ANOVA and the Tukey test were performed to verify differences between treatments. The experimental design was completely randomized, with a $95 \%$ confidence level.

\section{Results and Discussion}

\section{Color measurement}

The colorimetric parameters from thermally treated Eucalyptus grandis wood after $24 \mathrm{~h}$ and two years are in Table 1. The main cause of color changes in wood are related to the dissolution, oxidation and degradation of chemical compounds and extractives (VARGA; ZEE, 2008). In general, wood turns darker because of volatilization of extractives and phenolic compounds (MOURA; BRITO, 2011). The main extractive compounds which are responsible for color change in hardwood are terpenes, phenol and tannin (ISHIGURI et al., 2003).
The storage time moderately affected $\mathrm{L}^{*}$ and the wood surface of T1 samples, with losses of around 4\% in lightness after two years. CS presented the same behavior as $\mathrm{T} 1$, while $\mathrm{T} 2$ samples gained a small percentage of lightness. The wood in all groups showed higher $\mathrm{a}^{*}$ value and lower $\mathrm{b}^{*}$ value after 24 months. The color of T1, T2 and CS wood surfaces turned more positive on the red axis, and became positive on the blue axis. An increase in color intensity after two years of storage was noted for $\mathrm{T} 1$ and $\mathrm{T} 2$ due the calculation of the $\mathrm{C}$ value. However, the CS samples lost saturation during the period. This occurrence was observed also by Moura; Brito (2011), Cademartori et al. (2013), Garcia et al. (2014) and Zanuncio et al. (2014) for Eucalyptus grandis wood. Changes in the variable $\mathrm{a}^{\star}$ means the wood becomes more red/rose with time. Wood is affected by weather conditions, and color instability is also related to leaching caused by humidity and photo degradation (PASTORE et al., 2008; ROSU et al., 2010), right after the thermal treatment (24 h), the CS and T1 samples were classified as pink-grayish, but after two years they had turned light-pink. The color for T2 group was olive and changed to dark brown after two years. Garcia et al. (2014) reported that the original color of Eucalyptus grandis wood is light-pink, turning to dark brown due to thermal treatments. The authors also found, in another study, colors characterized as light-pink-grayish for same tree species (GARCIA et al., 2013).

The second measurement procedure was used after two years to analyze the wood surface color considering the tangential, radial and transversal axes (Table 2).

The color measured for CS between tangential and radial axes was not statistically different. Treatment T1 presented no meaningful changes when compared with CS, except for the variable $b^{*}$ on the transversal axis. For T2, the parameter which changed most was lightness. As also noticed by Cademartori et al. (2014) and Garcia et al. (2014), statistical 
Table 1. Average values and (standard deviation) of colorimetric parameters from thermally treated Eucalyptus grandis wood after $24 \mathrm{~h}$ and 2 years.

Tabela 1. Valores médios e (desvio padrão) dos parâmetros colorimétricos da madeira de Eucalyptus grandis tratada termicamente após 24 h e 2 anos.

\begin{tabular}{|c|c|c|c|c|c|c|}
\hline Time & $\begin{array}{c}\text { Treatment } \\
(\text { color })^{1}\end{array}$ & $\mathbf{L}^{*}$ & $\mathbf{a}^{*}$ & $\mathbf{b}^{*}$ & $\mathrm{C}$ & $\mathbf{h}^{\star}$ \\
\hline \multirow{3}{*}{$\underset{7}{\mp}$} & $\begin{array}{c}\text { CS } \\
\text { (rose-grayish) }\end{array}$ & $\begin{array}{c}68.68 \mathrm{~A} \\
(5.1)\end{array}$ & $\begin{array}{c}10.24 \mathrm{~B} \\
(1.6)\end{array}$ & $\begin{array}{c}21.58 \mathrm{~A} \\
(1.9)\end{array}$ & $\begin{array}{c}23.87 \mathrm{ABC} \\
(2.2)\end{array}$ & $\begin{array}{c}64.98 \mathrm{~A} \\
(3.0)\end{array}$ \\
\hline & $\begin{array}{c}\mathbf{T 1} \\
(\text { rose-grayish) }\end{array}$ & $\begin{array}{c}59.39 \text { B } \\
(6.9)\end{array}$ & $\begin{array}{c}9.67 \mathrm{~B} \\
(1.0)\end{array}$ & $\begin{array}{c}20.08 \mathrm{~B} \\
(1.3)\end{array}$ & $\begin{array}{c}22.30 \mathrm{BD} \\
(1.3)\end{array}$ & $\begin{array}{c}64.39 \mathrm{~A} \\
(2.8)\end{array}$ \\
\hline & $\begin{array}{c}\text { T2 } \\
\text { (olive green) }\end{array}$ & $\begin{array}{c}40.88 \mathrm{C} \\
(6.5) \\
\end{array}$ & $\begin{array}{c}8.62 \mathrm{C} \\
(0.7) \\
\end{array}$ & $\begin{array}{c}17.01 \mathrm{C} \\
(3.8) \\
\end{array}$ & $\begin{array}{c}19.01 \mathrm{E} \\
(3.6) \\
\end{array}$ & $\begin{array}{c}62.35 \text { B } \\
(4.1) \\
\end{array}$ \\
\hline \multirow{3}{*}{$\underset{⿱}{\stackrel{D}{*}}$} & $\begin{array}{c}\text { CS } \\
\text { (light pink) }\end{array}$ & $\begin{array}{c}63.24 \mathrm{~A} \\
(5.3)\end{array}$ & $\begin{array}{c}12.39 \mathrm{~A} \\
(2.1)\end{array}$ & $\begin{array}{c}20.04 \mathrm{AB} \\
(2.1)\end{array}$ & $\begin{array}{c}23.63 \mathrm{~A} \\
2.5)\end{array}$ & $\begin{array}{c}58.41 \mathrm{C} \\
(4.0)\end{array}$ \\
\hline & $\begin{array}{c}\mathbf{T} \mathbf{1} \\
(\text { light pink) }\end{array}$ & $\begin{array}{c}57.04 \mathrm{~B} \\
(5.1)\end{array}$ & $\begin{array}{c}12.07 \mathrm{~A} \\
(1.4)\end{array}$ & $\begin{array}{c}19.76 \mathrm{AB} \\
(1.3)\end{array}$ & $\begin{array}{c}23.18 \mathrm{AB} \\
(1.7)\end{array}$ & $\begin{array}{c}58.67 \mathrm{C} \\
(2.4)\end{array}$ \\
\hline & $\begin{array}{c}\text { T2 } \\
\text { (dark brown) }\end{array}$ & $\begin{array}{c}41.24 \mathrm{C} \\
(4.9)\end{array}$ & $\begin{array}{c}10.27 \mathrm{~B} \\
(1.2)\end{array}$ & $\begin{array}{c}16.63 \mathrm{C} \\
(3.0)\end{array}$ & $\begin{array}{c}19.57 \mathbf{E} \\
(3.1)\end{array}$ & $\begin{array}{c}57.70 \mathrm{C} \\
(2.2)\end{array}$ \\
\hline
\end{tabular}

${ }^{1}$ The color definitions are based on Camargos; Gonçalez (2001). CS = Control Samples; T1 = Treatment $1\left(150{ }^{\circ} \mathrm{C} /\right.$ $4)$; T2 = Treatment $2\left(200{ }^{\circ} \mathrm{C} / 3 \mathrm{~h}\right)$. Different letters in the same column indicate statistical differences based on the Tukey test at $5 \%$ probability.

Table 2. Average values and (standard deviation) of colorimetric parameters from thermally treated Eucalyptus grandis wood in different surfaces, after 2 years.

Tabela 2. Valores médios e (desvio padrão) dos parâmetros colorimétricos da madeira de Eucalyptus grandis tratada termicamente em diferentes superfícies, após 2 anos.

\begin{tabular}{|c|c|c|c|c|c|c|c|c|c|c|c|}
\hline Axis & $\begin{array}{c}\text { Treatment } \\
\left(\text { color }^{1}\right)\end{array}$ & $\mathbf{L}^{*}$ & & & & $\mathbf{b}^{\prime}$ & & & & $\mathbf{h}^{*}$ & \\
\hline \multirow{3}{*}{ 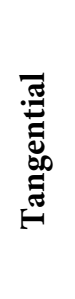 } & $\begin{array}{c}\text { CS } \\
(\text { light pink) }\end{array}$ & $\begin{array}{l}65.88 \\
(3.0)\end{array}$ & $\mathbf{A}$ & $\begin{array}{l}13.43 \\
(2.3)\end{array}$ & A & $\begin{array}{c}21.68 \\
(0.9)\end{array}$ & $\mathbf{A}$ & $\begin{array}{c}24.56 \\
(1.8)\end{array}$ & A & $\begin{array}{l}58.47 \\
(3.9)\end{array}$ & A \\
\hline & $\begin{array}{c}\mathbf{T 1} \\
(\text { light pink) }\end{array}$ & $\begin{array}{l}58.02 \\
(5.3)\end{array}$ & B & $\begin{array}{l}13.01 \\
(1.5)\end{array}$ & $A B$ & $\begin{array}{c}20.46 \\
(0.8)\end{array}$ & AB & $\begin{array}{l}24.27 \\
(1.2)\end{array}$ & AB & $\begin{array}{l}57.69 \\
(2.7)\end{array}$ & A \\
\hline & $\begin{array}{c}\mathbf{T} 2 \\
\text { (dark brown) }\end{array}$ & $\begin{array}{l}39.12 \\
(3.7)\end{array}$ & C & $\begin{array}{l}9.63 \\
(1.3)\end{array}$ & D & $\begin{array}{l}15.02 \\
(2.9)\end{array}$ & $\mathrm{D}$ & $\begin{array}{l}17.87 \\
(3.1)\end{array}$ & E & $\begin{array}{l}57.01 \\
(2.4)\end{array}$ & A \\
\hline \multirow{3}{*}{ 经 } & $\begin{array}{c}\text { CS } \\
\text { (light pink) }\end{array}$ & $\begin{array}{l}66.26 \\
(4.1)\end{array}$ & $\mathbf{A}$ & $\begin{array}{l}12.45 \\
(2.1)\end{array}$ & $A B$ & $\begin{array}{l}21.01 \\
(1.2)\end{array}$ & A & $\begin{array}{l}24.49 \\
(1.6)\end{array}$ & A & $\begin{array}{l}59.50 \\
(4.5)\end{array}$ & A \\
\hline & $\begin{array}{c}\text { T1 } \\
\text { (light pink) }\end{array}$ & $\begin{array}{l}59.35 \\
(4.8)\end{array}$ & B & $\begin{array}{l}12.22 \\
(1.1)\end{array}$ & $\mathrm{ABC}$ & $\begin{array}{c}10.36 \\
(0.9)\end{array}$ & $\mathbf{A B}$ & $\begin{array}{c}23.78 \\
(1.1)\end{array}$ & $\mathrm{ABC}$ & $\begin{array}{l}59.07 \\
(2.3)\end{array}$ & $\mathbf{A}$ \\
\hline & $\begin{array}{c}\mathbf{T 2} \\
\text { (dark brown) }\end{array}$ & $\begin{array}{l}43.20 \\
(5.5)\end{array}$ & C & $\begin{array}{l}11.00 \\
(0.9)\end{array}$ & BCD & $\begin{array}{l}18.39 \\
(2.7)\end{array}$ & BC & $\begin{array}{c}21.44 \\
(2.8)\end{array}$ & CD & $\begin{array}{c}58.92 \\
(1.8)\end{array}$ & A \\
\hline \multirow{3}{*}{ 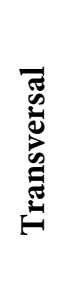 } & $\begin{array}{c}\text { CS } \\
\text { (light pink) }\end{array}$ & $\begin{array}{l}57.62 \\
(3.5)\end{array}$ & B & $\begin{array}{l}11.3 \\
(1.5)\end{array}$ & BCD & $\begin{array}{l}17.44 \\
(0.8)\end{array}$ & CD & $\begin{array}{c}20.84 \\
(1.1)\end{array}$ & D & $\begin{array}{l}57.26 \\
(3.8)\end{array}$ & $\mathbf{A}$ \\
\hline & $\begin{array}{c}\mathbf{T 1} \\
(\text { light pink) }\end{array}$ & $\begin{array}{l}53.74 \\
(3.4)\end{array}$ & B & $\begin{array}{l}10.98 \\
(0.9)\end{array}$ & BCD & $\begin{array}{l}18.44 \\
(1.0)\end{array}$ & BC & $\begin{array}{l}21.48 \\
(1.1)\end{array}$ & BCD & $\begin{array}{l}59.26 \\
(2.15)\end{array}$ & A \\
\hline & $\begin{array}{c}\mathbf{T} 2 \\
\text { (dark brown) }\end{array}$ & $\begin{array}{l}40.79 \\
(4.5)\end{array}$ & C & $\begin{array}{l}10.19 \\
(0.8)\end{array}$ & CD & $\begin{array}{l}16.47 \\
(2.6)\end{array}$ & $\mathrm{CD}$ & $\begin{array}{l}19.39 \\
(2.7)\end{array}$ & $\mathrm{DE}$ & $\begin{array}{l}57.98 \\
(2.3)\end{array}$ & $\mathbf{A}$ \\
\hline
\end{tabular}

${ }^{1}$ The color definitions are based on Camargos; Gonçalez (2001). CS = Control Samples; T1 = Treatment $1\left(150^{\circ} \mathrm{C} / 4 \mathrm{~h}\right) ; \mathrm{T} 2=$ Treatment $2\left(200^{\circ} \mathrm{C} / 3 \mathrm{~h}\right)$. Different letters in the same column indicate statistical differences based on the Tukey test at $5 \%$ probability. 
analysis showed no distinction between color in different wood axes of Eucalyptus grandis. The radial axis had a shiny surface, due to the wood rays' horizontal bands (BURGER; RICHTER, 1991). Although statistical differences were not observed, a tendency to higher $L^{\star}$ value in all thermally treated wood samples was noticed for the radial axis.

Color measurement on the transversal axis showed a darker wood surface. Gonçalez et al. (2001) reported that the presence of annual growth rings in transversal sections increases the gray level, decreasing the luminosity, $\mathrm{a}^{\star}$ and $\mathrm{b}^{\star}$ values, providing a darker aspect for wood in this anatomic axis. Following the color table of Camargos; Gonçalez (2001), the three anatomical axes were considered pink for CS. For all wood axes of T2 treatment, a darker brown color was reached. This fact reinforces the possibility of improving the visual appeal of light wood by heat treatment.

Total color variation $(\Delta \mathrm{E})$ of wood in each analysis and between them are reported in Table 3.

The biggest color change was observed between control samples and Treatment 2. Variations between treatments on each date remained in the same classification after $24 \mathrm{~h}$ and 2 years. When we compared each treatment with different storage time, control samples presented the highest variation, as expected in function of natural degradation and oxidation of chemical compounds in wood. Thermally treated wood also presented some color changes, which indicate that chemical transformations are continuous, but at a slow rate.

\section{Thermogravimetric Analysis}

The Figure 1 presents the thermal degradation behavior of CS, T1 and T2 groups after two years of storage. During this time, the samples did not undergo fungal or insect attack, so there were not significant mass losses. The small variation during the two years may be related to the hygroscopic characteristic of wood and change in the amounts of volatile organic compounds (VOCs). Mayes; Oksanen (2002) reported that VOC emissions from thermally treated wood were $90 \%$ lower than for air dried wood. This means that during the thermal treatment a large percent of VOCs already evaporated, so their quantity was not strongly affected by the storage time. Since thermogravimetric analyses aim to measure the mass loss due to temperature increase, and the mass did not drastically change, a single thermogravimetric analysis may be enough to understand the thermal decomposition of wood.

Thermal degradation of wood can be divided into three temperature regions. The first region $\left(100-200^{\circ} \mathrm{C}\right)$ refers to water loss and evaporation of extractives, the second region $\left(200-400{ }^{\circ} \mathrm{C}\right)$ involves the decomposition of major wood chemical constituents and the third region $\left(>400{ }^{\circ} \mathrm{C}\right)$ is attributed to complete wood decomposition (AYDEMIR et

Table 3. Total color variation of thermally treated Eucalyptus grandis wood after $24 \mathrm{~h}$ and 2 years.

Tabela 3. Variação total da cor da madeira de Eucalyptus grandis tratada termicamente após $24 \mathrm{~h}$ e 2 anos.

\begin{tabular}{cccc}
\hline Time & Treatment & $\boldsymbol{\Delta E}$ & Classification $^{\mathbf{1}}$ \\
\hline \multirow{2}{*}{$24 \mathrm{~h}$} & CS x T1 & 9.42 & Very appreciable \\
& CS x T2 & 28.23 & Very appreciable \\
\hline \multirow{2}{*}{2 years } & CS x T1 & 6.22 & Very appreciable \\
& CS x T2 & 22.36 & Very appreciable \\
\hline \multirow{2}{*}{$24 \mathrm{~h}$ x 2 years } & CS x CS & 6.08 & Very appreciable \\
& T1 x T1 & 3.41 & Appreciable \\
& T2 x T2 & 1.74 & Notable \\
\hline
\end{tabular}

${ }^{1}$ Classification based on Hikita et al. (2001). CS = Control Samples; T1 = Treatment $1\left(150^{\circ} \mathrm{C} / 4 \mathrm{~h}\right) ; \mathrm{T} 2=$ Treatment $2\left(200{ }^{\circ} \mathrm{C} /\right.$ $3 \mathrm{~h})$. 


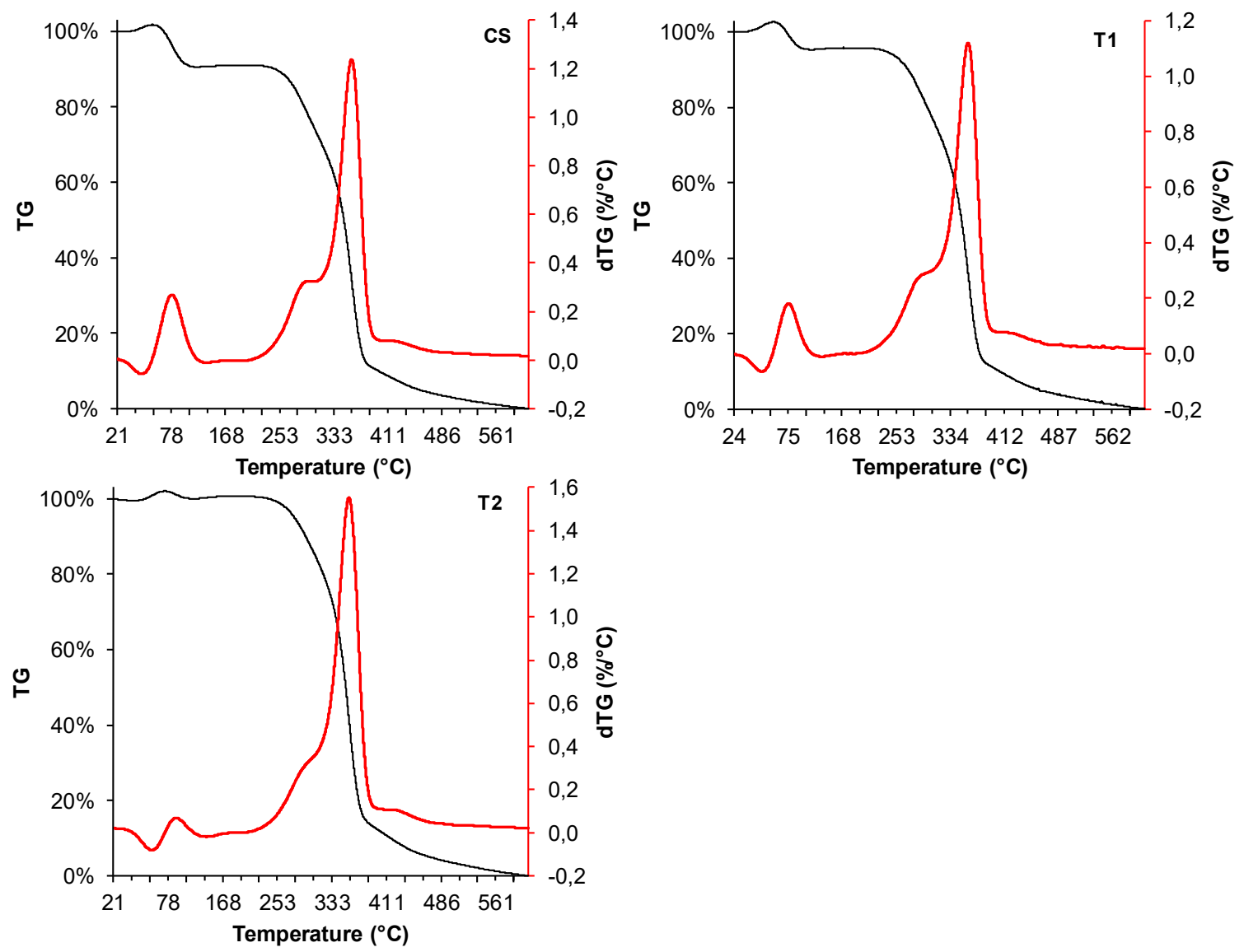

Figure 1. Thermal degradation and mass loss of Eucalyptus grandis wood in different treatments: CS = Control Samples; T1 = Treatment $1\left(150^{\circ} \mathrm{C} / 4 \mathrm{~h}\right) ; \mathrm{T} 2=$ Treatment $2\left(200^{\circ} \mathrm{C} / 3 \mathrm{~h}\right)$. The black curve $(\mathrm{TG})$ indicates mass loss (in \%) and red curve (dTG) corresponds to the first derivate of the TG curve and presents the rate of degradation (in \%) according to the temperature increase.

Figura 1. Degradação térmica e perda de massa da madeira de Eucalyptus grandis nos diferentes tratamentos: CS = Amostras controle; $\mathrm{T} 1=$ Tratamento $1\left(150^{\circ} \mathrm{C} / 4 \mathrm{~h}\right) ; \mathrm{T} 2=$ Tratamento $2\left(200^{\circ} \mathrm{C} / 3 \mathrm{~h}\right)$. A curva preta (TG) indica perda de massa (em $\left.\%\right)$ e a curva vermelha (dTG) corresponde à derivada do TG e apresenta a taxa de degradação (em \%) de acordo com o aumento da temperatura.

al., 2011). All samples presented higher thermal degradation (mass loss) at temperatures between $358^{\circ} \mathrm{C}$ and $360{ }^{\circ} \mathrm{C}$. This temperature range is similar to that reported by Pereira et al. (2013) in a study involving thermogravimetric analysis of six different Eucalyptus spp. clones.

The Table 4 presents the mass loss for all sample groups during the thermogravimetric analysis, as well as the residual mass.

During the initial heating, from ambient temperature to $100{ }^{\circ} \mathrm{C}$, the highest mass loss was observed for CS samples. The mass loss for $\mathrm{T} 1$ and $\mathrm{T} 2$ samples in the same temperature region was lower, respectively $2.85 \%$ and $0.39 \%$. Aydemir et al. (2011) investigated changes in the chemical constituents of heat-treated wood and observed lower mass loss in the first degradation region for thermally treated samples compared to control specimens. The evaporation of bonded water of CS samples (present inside the cell wall) can explain this fact.

Mass loss between 100 and $200{ }^{\circ} \mathrm{C}$ was minimal for all treatments. Pereira et al (2013) also noted a small mass loss in this temperature region when investigating Eucalyptus spp wood by thermogravimetry. On the other hand, Poletto et al. (2012a) observed higher mass loss at temperatures around $180-190^{\circ} \mathrm{C}$ for Eucalyptus grandis and other species.

From $200{ }^{\circ} \mathrm{C}$ to $300^{\circ} \mathrm{C}$, high mass loss was observed. 
Table 4. Mass loss and the residual mass of thermally treated Eucalyptus grandis wood.

Tabela 4. Perda de massa e massa residual da madeira de Eucalyptus grandis tratada termicamente.

\begin{tabular}{lcccccccc}
\hline Treatment & \multicolumn{3}{c}{ Mass loss (\%) at different temperature ranges $\left({ }^{\circ} \mathrm{C}\right)$} & \multicolumn{2}{c}{$\begin{array}{c}\text { Residual mass } \\
(\%)\end{array}$} \\
\hline & $\mathbf{2 5 - 1 0 0}$ & $\mathbf{1 0 0 - 2 0 0}$ & $\mathbf{2 0 0 - 3 0 0}$ & $\mathbf{3 0 0 - 3 5 0}$ & $\mathbf{3 5 0 - 4 0 0}$ & $\mathbf{4 0 0 - 5 0 0}$ & $\mathbf{5 0 0 - 6 0 0}$ \\
CS & 8.43 & 0.49 & 14.89 & 28.80 & 37.61 & 6.80 & 2.85 & 0.13 \\
T1 & 2.85 & 0.07 & 15.56 & 29.26 & 40.35 & 7.27 & 3.15 & 0.17 \\
T2 & 0.39 & 0.24 & 12.33 & 33.30 & 42.92 & 8.48 & 3.46 & 0.15 \\
\hline
\end{tabular}

$\mathrm{CS}=$ Control Samples; $\mathrm{T} 1=$ Treatment $1\left(150^{\circ} \mathrm{C} / 4\right.$ hours $) ; \mathrm{T} 2=$ Treatment $2\left(200^{\circ} \mathrm{C} / 3\right.$ hours $)$.

Wang et al. (2007) reported a high cellulose decomposition in the temperature range of $277-397^{\circ} \mathrm{C}$. The lower mass loss for $\mathrm{T} 2$ compared to the other sample groups can be attributed to the fact that previous degradation of hemicelluloses and cellulose occurred during the thermal treatment. Poletto et al. (2012a) observed degradation of hemicelluloses at around $300{ }^{\circ} \mathrm{C}$ in Eucalyptus grandis and three other species, and related it to the amorphous structure, which can be easily hydrolyzed.

The highest thermal degradation occurred between 300 ${ }^{\circ} \mathrm{C}$ and $400{ }^{\circ} \mathrm{C}$. According to Chaouch et al. (2012), the peak mass loss for cellulose happens after the hemicellulose degradation. They stated that higher energy is needed for the depolymerization of cellulose chains, causing monomers to crack. This fact can explain the thermally treated wood's behavior when compared to CS. T1 and T2 lost more mass than the CS group, since the cellulose depolymerization already occurred during the thermal treatment.

Poletto et al. (2012b) concluded that composition and crystallinity of wood can influence thermal degradation. They observed that higher extractive content along greater reactivity of hemicelluloses and lignin can accelerate the degradation process. On the other hand, organized cellulose regions may prevent wood degradation as result of wellpacked cellulose chains, which interfere in the heat diffusion, promoting slower degradation.

A lower degradation rate was verified above $400{ }^{\circ} \mathrm{C}$. At this point, almost all residual hemicelluloses and cellulose content was already degraded. As cited by many authors, it is difficult to determine a specific degradation temperature for lignin, since it occurs in a wide temperature range until 900 ${ }^{\circ} \mathrm{C}$ (WANG et al., 2007; PEREIRA et al., 2013). All the samples presented a residual mass around $0.15 \%$. This mass is related to the extractives and ashes (thermal degradation products).

\section{Conclusions}

The thermal treatment changed the color of wood samples, confirmed by colorimetric measurement. Although the storage time affected the surface darkness of wood samples, turning it darker red, this change was not visible to the naked eye. The second measurement procedure showed no difference between tangential, radial and transversal wood surface.

The investigation by thermogravimetric analysis presented distinct behaviors for each sample group. The thermal treatment caused higher mass loss in the temperature range between $200{ }^{\circ} \mathrm{C}$ and $400{ }^{\circ} \mathrm{C}$, because of the previous cellulose depolymerization.

\section{References}

AYDEMIR, D.; GUNDUZ, G.; ALTUNTAS, E.; ERTAS, M.; SAHIN, H. T.; ALMA, H. Investigating changes in the chemical constituents and dimensional stability of heattreated hornbeam and uludag fir wood. Bioresources, v. 2, n. 6, p.1308-1321, 2011.

BURGER, L.M.; RICHTER, H.G. Anatomia da madeira. Nobel, 1991.154 p. 
CADEMARTORI, P.H.G.; SCHNEID, E.; GATTO, D.A; STANGERLIN, D.M.; BELTRAME, R. Thermal modification of Eucalyptus grandis wood: variation of colorimetric parameters. Maderas, Ciencia y tecnología, v. 15, n. 1, p. $57-$ 64, 2013.

CADEMARTORI, P.H.G.; MATTOS, B.D.; MISSIO, A.L.; GATTO, D.A. Colour responses of two fast-growing hardwoods to two-step steam heat treatments. Materials Research, v. 17, n. 12, p. 487-493, 2014.

CALONEGO, F.W.; SEVERO, E.T.D.; LATORRACA, J.V.F. Effect of thermal modification on the physical properties of juvenile and mature woods of Eucalyptus grandis. Floresta e Ambiente, v. 21, n.1, p. 108-113, 2014.

CAMARGOS, J.A.A.; GONÇALEZ, J.C. A colorimetria aplicada como instrumento na elaboração de uma tabela de cores de madeira. Brasil Florestal, n.71, p. 30-41, 2001.

CHAOUCH, M; DUMARÇAY, S; PÉTRISSANS, A; PÉTRISSANS, M; GÉRARDIN, P. Effect of heat treatment intensity on some conferred properties of different European softwood and hardwood species. Wood Science and Technology, v. 47, n.4; p. 663-673, 2012.

ESTEVES, B.M.; PEREIRA, H.M. Wood modification by heat treatment: a review. Bioresources, v.1, n.4, p. 370-404, 2009.

GARCIA, R.A.; OLIVEIRA, N.S. de; NASCIMENTO, A.M. do; SOUZA, N.D. de. Colorimetria de madeiras dos gêneros Eucalyptus e Corymbia e sua correlação com a densidade. Cerne, v. 20, n. 4, p. 509-517, 2013.

GARCIA, R.A.; LOPES, J.O. de; SANTOS, W.A. Modificação da cor original da madeira de Eucalyptus grandis através de tratamentos termorretificadores. Cerne, v. 20, n. 3, p. 449457, 2014.

GONÇALEZ, J.C.; JANIN, G.; SANTORO, A.C.S.; COSTA, A.F.; VALLE, A.T. Colorimetria quantitativa: uma técnica objetiva de determinar a cor da madeira. Brasil Florestal, n.72, 2001.

HILL, C.A.S. Wood modification: chemical, thermal and other processes. John Wiley \& Sons Ltd, 2006. 25p.

HIKITA,Y.; TOYODA, T.; AZUMA, M. Weathering testing of timber - discoloration. In: IMAMURA, Y. High performance utilization of wood for outdooor uses. Kyoto, Japao: Press-net, 2001.
ISHIGURI, F.; MARUYAMA, S.; TAKAHASHI, K.; ABE, Z.; YOKOTA, S.; ANDOH, M.; YOSHIZAWA, N. Extractives relating to heartwood color changes in sugi (Crytomeria japonica) by a combination of smoke-heating and UV radiation exposure. Journal of Wood Science, v. 49, n.2, p135, 2003

MAYES, D.; OKSANEN, O. Thermowood Handbook, Thermowood, Finnforest, Stora, 2002.

MORI, C.L.S.O. de; MORI, F.A.; LIMA, J.T.; TRUGILHO, P.F.; OLIVEIRA, A.C. Influência das características tecnológicas na cor da madeira de eucaliptos. Ciência Florestal, v. 14; n. 2, p. 123-132, 2004.

MOURA, L.F.; BRITO, J.O. Efeito da termorretificação sobre as propriedades colorimétricas das madeiras de Eucalyptus grandis e Pinus caribaea var. hondurensis. Scientia Forestalis, v. 39, n. 89, p. 69-76, 2011.

MOURA, L.F.; BRITO, J.O.; SILVA JR., F. G. da. Effect of thermal treatment on the chemical characteristics of wood from Eucalyptus grandis W. Hill ex Maiden under different atmospheric conditions. Cerne, v. 18, n. 3, p. 449-455, 2012a.

MOURA, L.F.; BRITO, J.O.; BORTOLETTO JR., G. Efeitos da termorretificação na perda de massa e propriedades mecânicas de Eucalyptus grandis e Pinus caribaea var. hondurensis. Revista Floresta, v. 42, n. 2, p. 305-314, 2012b.

PASTORE, T.C.M.; OLIVEIRA, C.C.K. de; RUBIM, J.C.; SANTOS, K. O. Efeito do intemperismo artificial em quatro madeiras tropicais monitorado por espectroscopia de infravermelho. Química Nova, v. 31, n. 8, p. 2071-2075, 2008.

PEREIRA, B.L.C.; CARNEIRO, A.C.O.; CARVALHO, A.M.M.L.; TRUGILHO, P.F.; MELO, I.C.N.A.; OLIVEIRA, A.C. Estudo da degradação térmica da madeira de Eucalyptus através de termogravimetria e calorimetria. Revista Árvore, v. 37, n. 3, p. 567-576, 2013.

POLETTO, M.; ZATTERA, A.J.; FORTE, M.M.C.; SANTANA, R.M.C. Thermal decomposition of wood: influence of wood components and cellulose crystallite size. Bioresource Technology, n.109, p.148-153, 2012a.

POLETTO, M.; ZATTERA, A.J.; SANTANA, R.M.C. Thermal decomposition of wood: kinetics and degradation mechanisms. Bioresource Technology, n.126, p.7-12, 2012 b.

ROSU, D.; TEACA, C.A.; BODIRLAU, E; ROSU, L. FTIR and color change of the modified wood as result of artificial light 
irradiation. Journal of Photochemistry and Photobiology, v. 3, n. 99, p. 144-149, 2010.

SANDBERG, D.; KUTNAR, A. Recent development of thermal wood treatments: Relationship between modification processing, product properties, and the associated environmental impacts. International Association of Wood Products Societies (IAWPS). Tokyo, 2015.

SUNDQVIST, B.; MORÉN, T. The influence of wood polymers and extractives on wood colour induced by hydrothermal treatment. Holz als Roh- und Werkstoff, v. 60, p. 375-376, 2002.

\section{THERMOWOOD ${ }^{\circledR}$. Production statistic 2016.}

VARGA, D.; ZEE, M.E. Influence of steaming on selected wood properties of four hardwood species. Holz als Roh-und Werstoff, v. 66, n. 1, p.11-18 2008.

WANG, S; LIU, Q.; LUO, Z.; WEN, L.; CEN, K. Mechanism study on cellulose pyrolysis using thermogravimetric analysis coupled with infrared spectroscopy. Front. Energy, v. 4, n. 1, p.413-419, 2007.

ZANUNCIO, A.J.V.; NOBRE, J.R.C.; MOTTA, J.P.; TRUGILHO, P.F. Química e colorimetria da madeira de Eucalyptus grandis W. Mill ex Maiden termorretificada. Revista Árvore, v. 38, n. 4, p. 765-770, 2014. 